\title{
Reflections on COVID-19 and the viability of curriculum adjustment and delivery options in the South African educational space
}

\begin{tabular}{|c|c|}
\hline \multicolumn{2}{|c|}{$\begin{array}{l}\text { Authors: } \\
\text { Hosea O. Patrick }{ }^{1} \text { (D) } \\
\text { Rhoda T.I. Abiolu } \\
\text { Oluremi A. Abiolu }\end{array}$} \\
\hline \multicolumn{2}{|c|}{$\begin{array}{l}\text { Affiliations: } \\
{ }^{1} \text { Global Migration and } \\
\text { Community Development, } \\
\text { Faculty of Built Environment } \\
\text { and Development Studies, } \\
\text { University of KwaZulu-Natal, } \\
\text { Durban, South Africa }\end{array}$} \\
\hline \multicolumn{2}{|c|}{$\begin{array}{l}{ }^{2} \text { The Centre for General } \\
\text { Education, Durban University } \\
\text { of Technology, Durban, } \\
\text { South Africa }\end{array}$} \\
\hline \multicolumn{2}{|c|}{$\begin{array}{l}{ }^{3} \text { The Federal University of } \\
\text { Technology, Akure, Nigeria }\end{array}$} \\
\hline \multicolumn{2}{|c|}{$\begin{array}{l}\text { Corresponding author: } \\
\text { Hosea Patrick, } \\
\text { patrickh@ukzn.ac.za }\end{array}$} \\
\hline \multicolumn{2}{|c|}{$\begin{array}{l}\text { Dates: } \\
\text { Received: } 23 \text { Oct. } 2020 \\
\text { Accepted: } 18 \text { Feb. } 2021 \\
\text { Published: } 05 \text { May } 2021\end{array}$} \\
\hline \multicolumn{2}{|c|}{$\begin{array}{l}\text { How to cite this article: } \\
\text { Patrick, H.O., Abiolu, R.T.I. \& } \\
\text { Abiolu, O.A., 2021, } \\
\text { 'Reflections on COVID-19 } \\
\text { and the viability of } \\
\text { curriculum adjustment and } \\
\text { delivery options in the South } \\
\text { African educational space', } \\
\text { Transformation in Higher } \\
\text { Education } 6(0) \text {, a101. https:// } \\
\text { doi.org/10.4102/the.v6i0.101 }\end{array}$} \\
\hline \multicolumn{2}{|c|}{$\begin{array}{l}\text { Copyright: } \\
\text { (c) 2021. The Authors. } \\
\text { Licensee: AOSIS. This } \\
\text { is licensed under the } \\
\text { Creative Commons } \\
\text { Attribution License. }\end{array}$} \\
\hline \multicolumn{2}{|l|}{ Read online: } \\
\hline 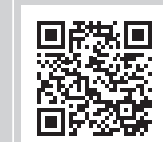 & $\begin{array}{l}\text { Scan this QR } \\
\text { code with your } \\
\text { smart phone or } \\
\text { mobile device } \\
\text { to read online. }\end{array}$ \\
\hline
\end{tabular}

Background: The coronavirus disease (COVID-19) pandemic brought unprecedented changes leading to 'business unusual' in all facets of life and livelihood on a global scale. The restrictions on gathering, social distancing and lockdown measures necessitated by the need to curtail its spread, had, and still have an enormous impact on the educational sector as indeed all spheres of life. These measures implied a change in the traditional modus operandi of curriculum and delivery options for educational institutions in South Africa in the bid to continue academic sessions. Hence, a transition of educational institutions from physical interactions to virtual meetings and the need to evolve curriculum contents and delivery.

Aim: With the peculiarity of the South African socioeconomic and political space, this article assessed the viability of curriculum change and delivery options (e-teaching and learning) for both students and instructors in the higher institution and the varied implications. It drew from discourses around the theory of localisation within educative context to create a more student-centred approach especially with the situation of less physical contact.

Setting: The discourse is set within the South African educational space.

Method: Considering the novelty of Covid-19 research and the challenge of contact, the study adopted a participatory action desktop research method to collect and analyse secondary data. The article vividly discussed how institutions transitioned to a localisation of frameworks and policies to ensure successful academic sessions.

Results: The educational landscape in South Africa is still plagued with historical antecedents of social injustice, funding, and resource allocation as well as the ever-present pressure of making education affordable to majority of local students. Also, the weakness of the online teaching methods to the physical contact method for learners and practitioners could be summed up into the issues of connectivity, technical knowledge, and attention span.

Conclusion: The conclusion enumerated the need for the implementation of policies and frameworks on proper utilisation of online systems to adjust to the demands of less contactbased approaches in favour of virtual approaches. The study called for adequate consideration to issues around the localisation of teaching and learning techniques considering the peculiarities of South Africa with focus on the opportunities, feasibility, and challenges of online measures especially for those in economically disadvantaged spaces.

Keywords: COVID-19; curriculum adjustment; e-Learning; internet accessibility; delivery options; South Africa; localisation.

\section{Introduction}

The coronavirus disease (COVID-19) has been declared by the World Health Organization (WHO) as a global pandemic owing to its spread across the globe (WHO 2020). The devastating effect of this disease has led to the literal standstill of world socioeconomic and political operations and the crippling of most sectors of states' and global economies. The impact of COVID-19 on the educational sector has been enormous bearing in mind the many obvious policy responses adopted since the emergence of the disease. At least, an average of 1.6 billion students are out of school in over 161 countries because of the COVID-19 pandemic (Saavedra 2020). Institutions in Africa are left to grapple with the problems this pandemic poses in terms of completing their academic calendars, even as developed countries continue e-teaching and learning.

Various levels of lockdown, face masks and the use of 'physical distancing' (otherwise known as social distancing) were proposed by policymakers around the world as strategies to curtail the 
spread of the disease (Ramaphosa 2020; South African Government 2020a). To this effect, the South African government announced a restriction on all forms of gatherings, apart from essential activities related to health and funerals in the early phase of the pandemic in the republic (South African Government 2020a). By implication, the educational sector took a big knock as campus-based interactions became prohibited and universities resorted to virtual meetings. Institutions and colleges traditionally engaged largely in contact teaching and learning were encouraged to shift to remote (digital, analogue delivery of learning materials) and e-teaching and learning (South African Government 2020b). The rationale for this decision was based on the need to ensure low risk of contracting and spreading the virus. The consequence of this policy directive for the educational system is enormous because the traditional mode of teaching adopted for most institutions in South Africa was via physical contact (Cruywagen \& Potgieter 2020; Motala \& Menon 2020).

The challenge this pandemic posed is vast as it brings to bear the issue of vertical and horizontal inequalities in terms of policy response and effect on the part of states, government and students. It is pertinent to note that whilst these governmental measures are a requirement, the end of these measures and the pandemic itself is not in near sight. This implies that as the world grapples and struggles to recover from the effects of the pandemic, the educational sector, like every other, will take a knock. Institutions of learning are forced to evolve curriculum contents and delivery given the peculiar situation the system finds itself (Crawford et al. 2020; Shoba 2020). Hence, delivery options by institutions have been the movement towards the use of online teaching rather than physical contact delivery options. The implication of this mode of delivery for institutions, staff and students, is of pertinent concern considering the peculiarities of the South African historicity and socioeconomic landscape (Ndebele 2020).

Using the theory of localisation within the educative context, the article provides a commentary on the peculiarities of the South African educational system in view of the necessities of curriculum adjustment as a mechanism for teaching and learning sustainability in the COVID-19 new normal. The article assesses the viability of curriculum change (and adjustment) and delivery options (e-teaching and learning) for both students and instructors in higher institutions bearing in mind the nation's socioeconomic, cultural and political configuration.

\section{A succinct contextualisation of the South African educational landscape}

It is no gainsaying that the COVID-19 pandemic has brought with it a gradual change in the world order leading to 'business unusual' in all facets of life and livelihood. The implications of the pandemic and the measures taken thus far in curtailing its spread imply a change in the traditional curriculum and delivery options for educational institutions. Government restrictions on large gathering because of the COVID-19 pandemic dictated a shift in the traditional technique of teaching and learning into an online method (Mpungose 2020b). These measures saw an increase in the use of online alternatives such as Zoom, WhatsApp, Moodle, Blackboard and e-mails for teaching and learning across all educational spaces (Mhlanga \& Moloi 2020; Motala \& Menon 2020; Mpungose 2020a). Whilst the transfer to these modes of teaching seemed the viable option to adopt for an unabated academic year, its socioeconomic and psychological implications for curriculum adjustment, 'disadvantaged' students and educators required further discourse and considerations. A gap promptly filled by this discourse.

South Africa has 26 public higher institutions of learning (11 general academic universities, nine comprehensive universities and six universities of technology), which are distributed within the nine provinces of the country (Department of Higher Education and Training n.d., 2018; Universities South Africa 2021). The 'core business' and essence of these public universities in South Africa are tied around 'producing excellent research, preparing a labour force, or addressing societal inequalities' (Swartz et al. 2019:567). However, the educational landscape is still plagued with historical antecedents of social injustice, funding and resource allocation and the ever-present pressure of making education affordable to the majority of local students (Statistics South Africa 2019; Swartz et al. 2019). Out of over 950000 students registered and enrolled in South African universities and technikons as of 2016, over 700000 students were black as presented by Statistics South Africa (2019:37), a whopping $72.6 \%$ of the entire student population all over the country (see Table 1 for a breakdown of racial categories). Reference to the black racial categorisation is because reports indicate that 'poverty is consistently highest amongst black South Africans' (Sulla \& Zikhali 2018: unnumbered).

Consequently, the need to contextualise the realities of South Africa's educational system is because of the historical configuration of economic privileges and systemic disadvantage with focus on the opportunities, feasibility and challenges of online measures especially for those in economically disadvantaged spaces (Letseka \& Pitsoe 2013; Letseka, Letseka \& Pitsoe 2018; Ndebele 2020).

\section{Theorising the localisation of teaching and learning techniques in South Africa: What is the reality?}

For the swift curriculum adjustment and delivery options within the South African educational landscape to be effective and efficient, it calls for adequate consideration to issues around the localisation of teaching and learning techniques considering the peculiarities of both advantaged and disadvantaged students (Ndebele 2020). This implies a review of the distinct socioeconomic, political, psychological and physiological factors of students and instructors. 
TABLE 1: Student enrolment in South African universities and technikons, 2016.

\begin{tabular}{|c|c|c|c|c|c|c|c|c|c|}
\hline \multirow{2}{*}{$\begin{array}{l}\text { Classification of educational subject matter (CESM) } \\
\text { category }\end{array}$} & \multicolumn{2}{|c|}{ Black } & \multicolumn{2}{|c|}{ Coloured } & \multicolumn{2}{|c|}{ Indian or Asian } & \multicolumn{2}{|c|}{ White } & \multirow[t]{2}{*}{ Total } \\
\hline & Number & $\%$ & Number & $\%$ & Number & $\%$ & Number & $\%$ & \\
\hline Agriculture, agricultural operations and related sciences & 15227 & 78.0 & 477 & 2.4 & 225 & 1.2 & 3584 & 18.4 & 19512 \\
\hline Architecture and the built environment & 7823 & 63.0 & 722 & 5.8 & 846 & 6.8 & 3022 & 24.3 & 12413 \\
\hline Visual and performing arts & 7853 & 57.1 & 1268 & 9.2 & 464 & 3.4 & 4170 & 30.3 & 13755 \\
\hline Business, economics and management studies & 192312 & 73.3 & 15526 & 5.9 & 16626 & 6.3 & 37947 & 14.5 & 262411 \\
\hline Communication, journalism and related studies & 15886 & 79.8 & 1527 & 7.7 & 514 & 2.6 & 1976 & 9.9 & 19902 \\
\hline Computer and information sciences & 30370 & 74.4 & 2597 & 6.4 & 2174 & 5.3 & 5682 & 13.9 & 40823 \\
\hline Education & 135463 & 76.7 & 10890 & 6.2 & 6678 & 3.8 & 23487 & 13.3 & 176518 \\
\hline Engineering & 58948 & 71.7 & 3412 & 4.1 & 5007 & 6.1 & 14856 & 18.1 & 82222 \\
\hline Health professions and related clinical sciences & 34931 & 58.9 & 5036 & 8.5 & 5616 & 9.5 & 13766 & 23.2 & 59350 \\
\hline Family ecology and consumer sciences & 2386 & 67.7 & 160 & 4.5 & 144 & 4.1 & 832 & 23.6 & 3522 \\
\hline Languages linguistics and literature & 14017 & 66.5 & 2432 & 11.5 & 787 & 3.7 & 3850 & 18.3 & 21086 \\
\hline Law & 40505 & 69.1 & 4514 & 7.7 & 3708 & 6.3 & 9900 & 16.9 & 58628 \\
\hline Life sciences & 18473 & 61.7 & 2132 & 7.1 & 1986 & 6.6 & 7370 & 24.6 & 29961 \\
\hline Mathematics and statistics & 10527 & 74.8 & 780 & 5.5 & 661 & 4.7 & 2101 & 14.9 & 14068 \\
\hline Military sciences & 6 & 100.0 & 0 & 0.0 & 0 & 0.0 & 0 & 0.0 & 6 \\
\hline Philosophy, religion and theology & 3355 & 52.1 & 877 & 13.6 & 245 & 3.8 & 1967 & 30.5 & 6444 \\
\hline Psychology & 17519 & 58.1 & 2824 & 9.4 & 1827 & 6.1 & 7994 & 26.5 & 30165 \\
\hline Public management and services & 30045 & 88.6 & 1730 & 5.1 & 655 & 1.9 & 1463 & 4.3 & 33893 \\
\hline Social sciences & 42890 & 83.2 & 3501 & 6.8 & 964 & 1.9 & 4191 & 8.1 & 51546 \\
\hline Total & 701474 & 72.6 & 61960 & 6.4 & 50450 & 5.2 & 152487 & 15.8 & 966371 \\
\hline
\end{tabular}

Source: Adapted from Statistics South Africa, 2019, Education series volume V higher education and skills in South Africa, 2017, p. 37, viewed 09 January 2021, from http://www.statssa.gov.za/ publications/Report-92-01-05/Report-92-01-052017.pdf

The motive is to provide an inclusive aura where no student is left behind considering the dent of the COVID-19 pandemic on academic activities. The availability of an inclusive and conducive educational environment both for facilitators and students is of utmost importance. And for e-Learning to be successful, a student-centred approach should be adopted (Council on Higher Education 2000; Department of Higher Education and Training 2001; Ndebele 2020; Yang 2010). The essence of a student-centred approach to e-teaching and learning is to cater to the needs of those students who are rather indigent and unable to cope with the challenges of education via technology (connectivity, remoteness, unaffordability of laptops and computers, etc.) (Cruywagen \& Potgieter 2020; Kumpu et al. 2016). However, it still begs the question, how can all these be achieved within the South African educational space?

Localisation of teaching and learning techniques recognises the importance of the culture and study environment and interests of the students (Ndebele 2020; Yang 2010). It brings into relatable terms, concepts, ideas, notions, global developmental, technological, economic and political frameworks within local contexts. Localisation seems rather preferable because a more global, rather than local approach, has led to internationalisation of higher education in Africa, but countries still struggle with resource allocation so as not to compromise quality or equity (Geo-JaJa 2013). Therefore, global educational practices are to be assimilated into local terrains and educational institutions considering the needs, cultures and traditions of such backgrounds (Cruywagen \& Potgieter 2020; Ndebele 2020; Olivier 2020). The relevance of the theory of localising teaching practices highlights the point that it can be a tool 'in education [to] create more values for local developments if local creativity and adaptation can be [encouraged] in the process of [localised] change' (Cheng 2002:2). What works in another educational space may not be ideal for another; that is the sole argument of the theory of localisation. In view of this, there is an additional notion that content rooted in cultural and geographical contexts, in local languages and day to day experiences are more acceptable (Jimes, Weiss \& Keep 2013; Ndebele 2020; Olivier 2020).

By fostering local knowledge for the development of the community and individuals (Cheng 2002; Ndebele 2020; Olivier 2020), the theory of localisation engages local networks and initiates discussions around the peculiarities within such milieus. This is an argument of this study, examining the localisation process of e-Learning and the implications of this for socially and economically disadvantaged students whose status remain unchanged further because of the limitations of COVID-19. In addressing the concept of localisation, because of the sudden change of delivery options as a result of the new order of COVID-19, there ought to be considerations for the state of e-Learning, internet accessibility and proliferation of technological devices within the South African landscape.

\section{e-Learning in the South African educational landscape}

e-Learning is an educational practice that is enhanced by the convergence of internet, computer and mobile technologies (Ali, Uppal \& Gulliver 2018; Azeez \& Van Der Vyver 2018; Ndebele 2020). It is 'flexible learning using Information Communications Technology (ICT) resources, tools and applications, focusing on; accessing information, interaction amongst teachers, students and the online environment, collaborative learning, and production of materials, resources 
and learning experiences' (Department of Education 2004:15). By learning with technology (e-Learning), facilitators find ways to appropriate technologies (information and communications technology [ICT]) to achieve meaningful learning and interactions thus exposing the students to a worldwide web of information (Bozalek \& Ng'ambi 2015:3; Zimba, Khosa \& Pillay 2020). Within this premise, the role of ICT is recognised as cogent in social transformation within the South African educational sector (Council on Higher Education 2000; Department of Education 2004; Department of Higher Education and Training 2001; Isaacs 2007; National Working Group 2002).

Information and communications technology practices range from emailing to online journaling, networked libraries, administration and developing creative software packages for the management of information tasks in teaching, examination and researching (Bagarukayo \& Kalema 2015:168). Other tools that have been used to facilitate active student engagement are YouTube, WhatsApp, blogs, podcasts and discussion forums online via laptops, desktops and mobile and wireless devices amongst others (Naidoo 2017; Zimba et al. 2020). Universities in South Africa engage e-Learning systems such as Zoom, Microsoft teams and Skype for web seminars (webinars), conference calls and videos to build interpersonal interactions (Mhlanga \& Moloi 2020; Mpungose 2020b).

Integrated into ICT practices are the learning management systems (LMS) employed by various universities such as Moodle and Blackboard, specifically localised into the institution's interactive network for staff, non-staff and students (Motala \& Menon 2020; Mpungose 2020a). These have been found to be successfully used for e-teaching and learning (Moonsamy \& Govender 2018; Mpungose 2020a). If LMS and ICT are properly applied alongside other technological tools identified here, they can further support and sustain productive teaching encounters. All that is required is to ensure that their guiding policies and principles are properly implemented and easily accessible to students, especially those who are disadvantaged (Motala \& Menon 2020; Mpungose 2020a).

e-Learning is not a new phenomenon within teaching spaces in South Africa (Bozalek \& Ng'ambi 2015; Ndebele 2020; Olivier 2020). What was obtainable was the fact that institutions did not completely depend on virtual assistance without human contact or interaction (that is blended learning - Cruywagen \& Potgieter 2020), as compared with now, in the era of COVID-19. Educative encounters were campus-based or facilitated online (Motala \& Menon 2020). But things are different now because universities all over the world, South Africa inclusive, are obligated to switch into a virtual system of learning with minimal or no physical contact (Crawford et al. 2020; South African Government 2020b). Therefore, the need of the hour is to switch to e-Learning in the face of the obstacles posed by COVID-19.
Pre-COVID-19, different trends were evident amongst students in their use of ICT for e-Learning. Students used ICT in support of their studies and as these became proliferated, institutions began to adopt more ICT techniques and LMSs for a more student-focused atmosphere (Brown \& Czerniewicz 2008). The study of Rohleder et al. (2008) revealed some positive and negative responses to e-Learning within South African universities pre-COVID-19. The study indicated that e-Learning facilitated easy correspondence between students and teachers. Another advantage was that information was readily available and access to learning materials was easier. However, the disadvantages students encountered were technical difficulties with power cuts and software challenges and unequal access to computers and laptops. They also encountered disjointed communication flow with facilitators and other students. For these reasons, the respondents preferred face to face interactions. Similarly, in another study, Kinuthia and Dagada (2008) reported that learning management systems and software packages have been advantageous for e-Learning in South African universities, but large class sizes, limited bandwidth, time and financial constraints hindered the effectiveness of e-Learning although students still showed enthusiasm about incorporating ICT into their learning encounters. The lack of technological know-how and readiness for the uptake of a new approach to teaching and learning for students and teachers has thus been of foremost concern (Coopasami, Knight \& Pete 2017; Stoltenkamp \& Kasuto 2011).

Scholars have foregrounded that online platforms are viable means by which dialogic communication and e-Learning can be established and fostered (Abiolu \& Teer-Tomaselli 2018; Bosch 2009; Bozalek \& Ng'ambi 2015; Cruywagen \& Potgieter 2020; Makoe 2010; Moonsamy \& Govender 2018; Ndebele 2020; Zimba et al. 2020). Student-lecturer engagement on online platforms takes on constantly interchangeable scenarios in which the producers of such contents, that is, the lecturers, at some point take on the role of their students as consumers, whilst the students take on the role of producers of educational content. This interchangeable role is appropriated to the concept of 'prosumers', an amalgamation of 'producers' and 'consumers', within the educational context (see Komoski 2007). This is the true essence of dialogic communication and a student-centred approach to teaching and learning (Freire 2005), which should be the aim of e-Learning within South Africa.

The efforts of institutions in creating inclusive online environments are poised to ensure that the social transformation agenda within the educational framework of South Africa is further entrenched and developed (Council on Higher Education 2000; Department of Education 2004; Department of Higher Education and Training 2001, 2018; Isaacs 2007; National Working Group 2002). These efforts are embedded in education and technology policies that guide e-Learning within South Africa. One of such effort is the policy concern of the Council on Higher Education (2000:31), which states that 'the higher education system must strive to 
achieve equity and aspire to excellence'. Another such effort is the White Paper on e-Education (August 2004), which also categorically states that if South Africans are to participate in the knowledge economy, every effort must be made to prevent social exclusion' (Department of Education 2004:10). The pertinent question we propose is how can social exclusion be prevented amongst socially disadvantaged groups in their access to education especially during this transition to e-Learning intensified by COVID-19?

Therefore, there is the need to contextualise the proliferation of internet and internet technology in South Africa, and the availability of these digital platforms, which prove to be vital to the success of e-Learning and active student engagement within South Africa (Masiu \& Chukwuere 2018; Zimba et al. 2020).

\section{Internet, mobile telephony, computer accessibility and government's strides}

To mitigate human contact, countries are adopting the virtual mode of connectivity and human interaction, visible in the facilitation of business meetings, conference calls and delivering of lectures to students (United Nations Educational, Scientific and Cultural Organization [UNESCO] Institute for Information Technologies in Education [IITE] 2020). Institutions of higher learning in South Africa have also instantly embraced internet technology to facilitate interactions between students and lecturers (Gerber 2020; Mhlanga \& Moloi 2020). Internet access in a globalised world opens the word to a flow of information and a borderless virtual community. As live updates and statistics are made available, people are kept abreast of current affairs relating to COVID-19, measures that governments around the world are taking, casualties, confirmed cases and those who have recovered, as well as efforts to make vaccines available to combat the virus (WHO 2020; Worldometers 2020). Access to the internet (through mobile phones or computers) is a major factor that is to be considered in this new reality the world finds itself in.

The growth in internet usage in South Africa has been exponential over the years. As of 2018, Statistics South Africa (2018:57) reported that $64.7 \%$ of South Africans had at least a member of the family who had access to the internet. There is an obvious disparity of data users depending on the places where they reside. Those who have internet access at home and live in the metropolitan areas across the country amount to $93.9 \%$, those in urban settlements amount to $77.4 \%$ whilst those in rural areas amount to $34.7 \%$ (Statistics South Africa 2018:58). Those who access the internet through cafés or educational facilities across all provinces are $81.4 \%$ for those in the metropolitan areas, $73.8 \%$ for those in the urban region and $31 \%$ for those in rural settlements (Statistics South Africa 2018:58) (see Table 2).

The statistics reveal the obvious disparity as a result of settlements. This comparison is peculiar because of the situations around lockdowns and having to stay at home, work from home or receive lectures from home (Mhlanga \& Moloi 2020; Mpungose 2020b). Those who had access through cafés and campuses face enormous obstacles of data connectivity. Although universities arranged for certain number of students to be back on campus, all within the COVID-19 safety regulations (Mpungose 2020b), these arrangements had to be shelved because of outbreaks of positive COVID-19 cases amongst staff, student and especially in student residences. And because of the limitedness of internet access and how expensive data purchases are, there is a great concern for students who dwell in rural communities (Mpungose 2020b).

On the other hand, access to mobile telephones and computers prove to be pivotal in the success of online teaching and learning (Cruywagen \& Potgieter 2020; Masiu \& Chukwuere 2018; Mhlanga \& Moloi 2020). Of those who own at least one computer, $29.6 \%$ of these stay in the metropolitan area, $21.3 \%$ stay in the urban areas and $8.8 \%$ stay in the rural areas (Statistics South Africa 2018:63). Ownership of computers seems to be luxurious as represented by the statistics (see Table 3 ).

However, mobile phone penetration in South Africa has experienced tremendous usage and subscription. Mobile telephone users of 2019 grew rapidly as compared with the statistics of the previous 3 years, which were $43.5 \%$ at 2016 , $74.2 \%$ at 2017 and $81.7 \%$ at 2018, indicated in Table 4 (ICASA 2019). Smartphone penetration stood at $91.2 \%$ in

TABLE 2: Statistics of internet access and data users.

\begin{tabular}{lc}
\hline Place of internet access & Percentage (\%) of all data users \\
\hline Access internet at home & \\
Metropolis & 93.9 \\
Urban areas & 77.4 \\
Rural regions & 34.7 \\
Access internet through cafés or educational & \\
facilities (campus, residences, libraries) & 81.4 \\
Metropolis & 73.8 \\
Urban areas & 31.0 \\
Rural regions & \\
Source: Adapted from Statistics South Africa, 2018, General household survey 2018, p. 58,
\end{tabular}

Source: Adapted from Statistics South Africa, 2018, General household survey 2018, p. 58 viewed 06 August 2020, from http://www.statssa.gov.za/publications/P0318/P03182018.pdf

TABLE 3: Computer ownership distribution by settlement.

\begin{tabular}{lc}
\hline Ownership of computer & Percentage (\%) \\
\hline Owners in & \\
Metropolis & 29.6 \\
Urban areas & 21.3 \\
Rural regions & 8.8 \\
\hline
\end{tabular}

Source: Adapted from Statistics South Africa, 2018, General household survey 2018, p. 63 viewed 06 August 2020, from http://www.statssa.gov.za/publications/P0318/P03182018.pdf

TABLE 4: Mobile phone proliferation in South Africa.

\begin{tabular}{lc}
\hline Growth in SA's mobile phone users & Percentage (\%) \\
\hline 2016 & 43.5 \\
2017 & 74.2 \\
2018 & 81.7 \\
2019 & 91.2 \\
\hline
\end{tabular}

Source: Adapted from ICASA, 2019, State of the ICT sector in South Africa - 2020 report p. 33-34, viewed 06 May 2020, from https://www.icasa.org.za/legislation-and-regulations/ state-of-the-ict-sector-in-south-africa-2020-report. 
2019, whilst close to 28 million South Africans have long term evolution (LTE) devices for internet connectivity (ICASA 2019:33-34).

The mobile telephone has paved the way as an emerging technology that is more affordable and accessible to provide online awareness, presence and literacy (Bozalek \& Ng'ambi 2015). Therefore, if computers are a luxury, mobile phones suffice in enabling e-Learning (see Masiu \& Chukwuere 2018).

Internet or mobile telephony or computer accessibility is a major challenge to pinpoint towards the success of e-Learning and a student-centred localised method of teaching and learning. But these do not by any means negate or relegate the strides of the government to cater to the needs of students. For instance, on a yearly basis, financial aid is offered by the National Student Financial Aid Scheme (NSFAS) to students whose families are below an income of R350 000 as a salary threshold for basic education, determined by the organisation (Department of Higher Education and Training 2018; NSFAS 2020a). This student bursary is a government initiative with the aim to assist underprivileged students in their academic journeys and to relieve their parents or guardians of such financial burdens because of their monetary incapability (NSFAS 2020a). Some of the items that the allowance covers include laptops, book and living allowances, some pocket money for their academic session and accommodation allowance. The Higher Education Minister, Blade Nzimande, affirmed that students who were registered for the NSFAS bursary year 2020 would have access to appropriate digital devices (tablets and laptops) to be procured by the government (Makinana 2020). The government, as well as higher institutions of education, also made provision for data bundles for staff and students across the country (Kubheka 2020). Strategies to ease student access to their allowances have also been made available through online proxy, which implies that the needs of these students can still be met, even if it is online (Maphanga 2020; NSFAS 2020b, 2020c). These palliative measures for students from underprivileged families, not only bridge the gap between those who can afford basic education and those who cannot afford it but also enable e-Learning. In line with the initiative of UNESCO, to grant every child the opportunity to have some form of basic education (UNESCO 2011), these initiatives are indications of strategic and localised planning within the transformative agenda of the South African educational system to cope with the uncertainties of the COVID-19 era.

However, in the bid to foster a conducive online community of teachers and students, it is vital that institutions of learning and especially the facilitators ensure that meaningful learning is achieved and accomplished. Therefore, the motivating factor should not just be the bid to conclude academic sessions but to create educative and participatory academic virtual environments that culminate into meaningful learning. Meaningful learning can only be measured or evaluated by aligning tasks with the learning outcome and teaching strategies of such interactions (Bozalek \& Ng'ambi 2015). In addition, and importantly, the facilitator must take cognisance of the student's prior knowledge, competencies, previous technological predisposition to learning, that is, computer anxiety or digital literacy and capabilities (Ali et al. 2018; Bozalek \& Ng'ambi 2015:3). The level of technological awareness amongst students can thus inhibit or aid educational encounters (Zimba et al. 2020). Tewari and Ilesanmi (2020) argued that prior to COVID-19, some of these students at higher institutions lacked adequate coping strategies and the ability to adapt within the university system because of low level of preparedness, unavailability of local resources or inputs and student support services amongst other factors. If, for instance, some of these students are not knowledgeable about how these platforms work, it is the sole responsibility of their institutions to provide userfriendly guidelines and tutorials through their LMSs to equip these students for active and engaging teaching and learning experiences (Moonsamy \& Govender 2018; Motala \& Menon 2020; Mpungose 2020a). The success of all these is dependent on the viability of online mode of teaching and learning.

\section{Assessing the practicality and implications of online pedagogy}

Scholars have argued that the use of e-teaching and learning is advantageous to the development of cultural, critical and operational skills for both students and facilitators (Azeez \& Van Der Vyver 2018; Isaacs 2007; Kaliisa \& Picard 2017; Mayisela 2013; Mpungose 2020b; Msomi \& Bansilal 2018; Zimba et al. 2020). Facilitators are also expected to be equipped with the knowledge about internet-mediated academic encounters seeing they are vital to achieving maximum success for e-teaching and learning in South Africa (Motala \& Menon 2020). This raises concerns about the 'technological pedagogical content and knowledge' (TPACK) framework amongst teachers and facilitators prior to the emergence of COVID-19, that is, their use, knowledge and experience of technology (O'Carroll 2011; Sebolai \& Ogutu 2012). Pre-COVID-19, there was an increasing awareness amongst educational facilitators in South Africa about the advantages of TPACK, which served as motivation to gain relevant knowledge on how to succeed in this innovative pedagogy (Conger, Krauss \& Simuja 2017; De Freitas \& Spangenberg 2019). This also served as a nudge and unconscious preparation for the new realities that COVID-19 ushered in.

Online pedagogy offers convenience and ease of engagement for facilitators and students in comparison with the traditional method (Mpungose 2020b; Ngubane-Mokiwa \& Letseka 2015). For instance, facilitators and students can be connected in different parts of the world from the comforts of their spaces, without having to be in physical contact before engaging with one another. Another advantage of online pedagogy provides users an unrestricted access to educational materials and resources available without being time bound (Msomi \& Bansilal 2018). In this manner, if an online interaction between the facilitator and students was 
documented or recorded, this can be uploaded for reference and for those who were unavailable to attend the class. It extends the class discussions beyond the typical class timing and students can further engage with one another and their facilitators outside the class lectures. This encourages peer-to-peer collaborative learning (Mpungose 2020b; Msomi \& Bansilal 2018).

However, with respect to socioeconomic and psychological consideration, we argue that the psychological support base innate in man is outrightly denied in a virtual environment in comparison to a present and physical process of teaching and learning (Motala \& Menon 2020). Physical interactions and body language, which are easily detectable in a physical classroom (Mpungose 2020b) are absent in the virtual space. The online methods deny educational practitioners (students and facilitators), social interactions needed for physical and mental alertness (Motala \& Menon 2020). This is also coupled with the loss of collaborative support in which physical interactions contribute to learning. When clarity is required, direct interactions with peers and faculty are needed in real-time. Again, we maintain that the traditional physical contact method, through a practical-based curriculum, which requires contact supervision and modelling (e.g. laboratory experiments, field works) is more advantageous than online supervision that portrays some level of remoteness. These barriers are located within the technology (T), individual (I), pedagogy (P) and enabling conditions (EC) of Ali et al. (2018). These are some of the inadequacies of e-Learning. Similarly, the traditional contact approach enables longer attention span amongst students compared with the online method. The online methods present the temptation of surfing other sites that are not educational and other distractions such as multitasking, which may hinder concentration and attention span as supported by various scholars (Ali et al. 2018; Fox, Rosen \& Crawford 2009; Msiza, Malatji \& Mphahlele 2020; Winter et al. 2010).

We cannot relegate the reality of the digital divide experienced by students in rural communities who are disadvantaged in terms of connectivity, and other challenges of literacy, curriculum design and delivery structure, amongst others hereby, creating some level of inequality (Letseka \& Pitsoe 2013; Letseka et al. 2018; Ndebele 2020). Be that as it may, the option of transiting into the online teaching method in the light of the pandemic has become a necessary alternative to keep the education sector running and safeguard the lives of facilitators and students, in keeping with health regulations (Motala \& Menon 2020; Mpungose 2020b). In the same vein, scholars have foregrounded that this option can be successfully sustained if it is well applied locally and correctly managed (Azeez \& Van Der Vyver 2018; Masiu \& Chukwuere 2018; Ndebele 2020; Zimba et al. 2020). However, addressing South Africa's peculiarities in terms of internet accessibility, computer literacy and social inequalities are still fundamental policy and economic considerations for disadvantaged students engaging in e-Learning (Cruywagen \& Potgieter
2020; Mayisela 2013; Mhlanga \& Moloi 2020; Motala \& Menon 2020; Mpungose 2020b; Ngubane-Mokiwa \& Letseka 2015; Kaliisa \& Picard 2017; Zimba et al. 2020).

\section{Concluding remarks}

We assessed the viability of e-Learning in comparison to contact teaching and the obstacles or barriers to the successful running of this method of teaching and learning in the new COVID-19 normal. These are called to view considering the unprecedented challenge of the COVID-19 in adjusting to online teaching. The weakness of the online teaching methods in comparison to the physical contact method for students and practitioners could be summed up into three fundamental concerns. These are the issues of connectivity (in terms of internet access), technical knowledge or know-how (in terms of use of computers and other electronic teaching and learning aids) and attention span. Again, the significance of these issues vis-à-vis the South African peculiarity cannot be ignored as a significant proportion of students are not only faced with the challenge of connectivity and internet access but also with little or no knowledge on the use of digital devices. Even for those who have access and can operate these technologies, the need to maintain attention during online teaching is another task. It is plausible to posit that if these issues are adequately addressed, it will significantly shift the tide for effective online teaching as a preferable option for learning in the new world order created by the COVID-19 pandemic.

Furthermore, it is left to observe how South Africa's educational sector navigates around the somewhat unimplemented national policy framework on how to integrate technological convergence and advancements into tangible and best practices for the educational sector. With the uncertainty of the COVID-19 pandemic, there is the need for revisiting these policies (Council on Higher Education 2000; Department of Education 2004; Isaacs 2007; National Working Group 2002), and frameworks on proper utilisation of online systems to continue the seamless transition from campus-based approaches to virtual nationwide. As stated in the White Paper on e-Education of August 2004, implementation of policies around e-teaching and learning must 'transcend the mere exchange of information and [be] transform[ed] into a range of [creative and inclusive] learning activities that meet educational objectives [to ensure] the meaningful interaction of students with information' in South Africa (Department of Education 2004:14). The reality of this policy statement must be plausible during this time of dire need within the educational sector and in the equitable distribution and access to educational resources.

\section{Acknowledgements Competing interests}

The authors declare that they have no financial or personal relationships that may have inappropriately influenced them in writing this article. 


\section{Authors' contributions}

We all had different sections that we contributed to. H.O.P. conceptualised the idea, developed certain sections and assigned other sections to co-authors R.T.I.A. and O.A.A. who also fulfilled their quota. All authors proofread for correctness, before submitting the article for review.

\section{Ethical considerations}

This article followed all ethical standards for research without direct contact with human or animal subjects.

\section{Funding information}

This research received no specific grant from any funding agency in the public, commercial or not-for-profit sectors.

\section{Data availability}

Below are links to public datasets that were accessed.

Department of Basic Education (2020) School Realities Report. https: / / www.education.gov.za/Portals / 0 / Documents / Reports/School\%20Realities\%202019\%20Final\%20.pdf?ver= 2020-02-07-101051-330

Department of Higher Education and Training (2001) Draft National Plan for HigherEducation in South Africa. http:/ / www.dhet.gov.za/HED\%20Policies/National\%20Plan\%20 on\%20Higher\%20Education.pdf

ICASA (2019) State of the ICT Sector in South Africa 2020 Report. https://www.icasa.org.za/legislation-andregulations/state-of-the-ict-sector-in-south-africa-2020-report

Statistics South Africa (2018) General Household Survey 2018. http://www.statssa.gov.za/publications/P0318/P0318 2018.pdf

WHO (2020) Coronavirus disease (COVID-19) Pandemic. https: / / www.who.int/emergencies / diseases / novelcoronavirus-2019

Worldometer (2020) COVID-19 coronavirus pandemic. https: / www.worldometers.info/coronavirus /

\section{Disclaimer}

The views, opinions and statements in this article are those of the authors and are not necessarily reflections of the official policy of any affiliated agency of the authors.

\section{References}

Abiolu, R. \& Teer-Tomaselli, R., 2018, 'Media broadcasters as agents of participatory communication through audience involvement: MultiChoice's strategies', Critical Arts 32(5-6), 1-16. https://doi.org/10.1080/02560046.2018.1552979

Ali, S., Uppal, M.A. \& Gulliver, S.R., 2018, 'A conceptual framework highlighting e-learning implementation barriers', Information Technology \& People 31(1), 156-180. https://doi.org/10.1108/ITP-10-2016-0246
Azeez, N.A. \& Van Der Vyver, C., 2018, 'Digital Education: Assessment of e-Learning and $\mathrm{m}$-Learning Adoption in Tertiary Institutions in South Africa', 2018 IEEE Conference on e-Learning e-Management and e-Services (IC3e), Langkawi, Malaysia, on e-Learning, e-Management and e-Services (IC3e), Langkawi, Malaysia,
November 21-22, 2018, pp. 23-28. https://doi.org/10.1109/IC3e.2018.8632654.

Bagarukayo, E. \& Kalema, B., 2015, 'Evaluation of e-Learning usage in South African universities: A critical review', International Journal of Education and Development using Information and Communication Technology 11(2), 168-183.

Bosch, T.E., 2009, 'Using online social networking for teaching and learning: Facebook use at the University of Cape Town', Communicatio: South African Journal for Communication Theory and Research 35(2), 185-200. https://doi.org/10.1080/ 02500160903250648

Bozalek, V. \& Ng'ambi, D., 2015, 'The context of learning with technology', in W.R. Kilfoil (ed.), Moving beyond the hype: A contextualised view of learning with technology in higher education, A publication of the teaching and learning strategy group of Universities South Africa (universitiessa), pp. 1-7, Universities South Africa, Pretoria.

Brown, C. \& Czerniewicz, L., 2008, 'Trends in student use of ICTs in higher education in South Africa', in South Africa's 10th annual conference of WWW application, Cape Peninsula University of Technology, Cape Town, South Africa, September 03-06, 2008, n.p.

Cheng, C.Y., 2002, Fostering local knowledge and wisdom in globalized education: Multiple theories centre for research and international collaboration, Hong Kong Institute of Education, Hong Kong.

Conger, S., Krauss, K.E. \& Simuja, C., 2017, 'New pedagogical approaches with technologies', International Journal of Technology and Human Interaction 13(4) 62-76. https://doi.org/10.4018/IJTHI.2017100105

Coopasami, M., Knight, S. \& Pete, M., 2017, 'e-Learning readiness amongst nursing students at the Durban University of Technology', Health SA Gesondheid 22(1), 300-306. https://doi.org/10.1016/j.hsag.2017.04.003

Council on Higher Education, 2000, Towards a new higher education landscape: Meeting the equity, quality and social development imperatives of South Africa in the 21st century, viewed 09 January 2021, from http://196.13.185.8/docs/New HE Landscape.pdf

Crawford, J., Butler-Henderson, K., Rudolph, J., Malkawi, B., Glowatz, M., Burton, R. et al., 2020, 'COVID-19: 20 countries' higher education intra-period digital pedagogy responses', Journal of Applied Learning \& Teaching 3(1), 1-20. https:// doi.org/10.37074/jalt.2020.3.1.7

Cruywagen, S. \& Potgieter, H., 2020, 'The world we live in: A perspective on blended learning and music education in higher education', TD: The Journal for Transdisciplinary Research in Southern Africa 16(1), 1-9.

De Freitas, G. \& Spangenberg, E.D., 2019, 'Mathematics teachers' levels of technological pedagogical content knowledge and information and communication technology integration barriers', Pythagoras 40(1), 1-13. https://doi.org/10.4102/pythagoras. v40i1.431

Department of Education, 2004, White paper on e-Education transforming learning and teaching through information and communication technologies (ICTS), viewed 09 January 2021, from https://www.education.gov.za/Portals/0/Documents/ Legislation/White\%20paper/DoE\%20White\%20Paper\%207.pdf?ver=2008-0305-111708-000

Department of Higher Education and Training, 2001, Draft national plan for higher education in South Africa, viewed 11 May 2020, from http://www.dhet.gov.za/ HED\%2OPolicies/National\%2OPlan\%20on\%20Higher\%20Education.pdf.

Department of Higher Education and Training, 2018, Statistics on post-schoo education and training in South Africa: 2016, Released in March 2018, viewed 09 January 2021, from https://www.dhet.gov.za/Research\%20Coordination $\% 20$ Monitoring \%20and \%20Evaluation/6 DHET\%20Stats\%20Report_04\%20 April\%202018.pdf

Department of Higher Education and Training, n.d., Universities in South Africa, viewed 09 January 2021, from https://www.dhet.gov.za/SiteAssets/New\%20 site $\% 20$ Documents/Universities $\% 20$ in $\% 20$ South $\% 20$ Africa1.pdf

Fox, A.B., Rosen, J. \& Crawford, M., 2009, 'Distractions, distractions: Does instant messaging affect college students' performance on a concurrent reading comprehension task?', CyberPsychology \& Behavior 12(1), 51-53. https://doi. org/10.1089/cpb.2008.0107

Freire, P., 2005, Pedagogy of the oppressed, 30th anniversary edn., Continuum International, New York, NY.

Geo-JaJa, M.A., 2013, 'Education localization for optimizing globalization's opportunities and challenges in Africa', in S. Majhanovich \& M.A. Geo-JaJa (eds.), Economics, aid and education, pp. 157-181, Sense Publishers, Rotterdam

Gerber, J., 2020, 'Blade's plan to save the academic year', news24, 14 May, viewed 18 May 2020, from https://m.news24.com/SouthAfrica/News/blades-plan-tosave-the-academic-year-20200514

ICASA, 2019, State of the ICT sector in South Africa - 2020 report, viewed 06 May 2020 fromhttps://www.icasa.org.za/legislation-and-regulations/state-of-the-ict-sectorin-south-africa-2020-report

Isaacs, S., 2007, 'ICT in education in South Africa', Survey of ICT and Education in Africa: South Africa Country Report 21, 15-54.

Jimes, C., Weiss, S. \& Keep, R., 2013, 'Addressing the local in localization: A case study of open textbook adoption by three South African teachers', Journal of Asynchronous Learning Networks 17(2), 73-86. https://doi.org/10.24059/olj.v17i2.359

Kaliisa, R. \& Picard, M., 2017, 'A systematic review on mobile learning in higher education: The African perspective', TOJET: The Turkish Online Journal of Educational Technology 16(1), 1-18.

Kinuthia, W. \& Dagada, R., 2008, 'E-learning incorporation: An exploratory study of three South African higher education institutions', International Journal on E-Learning 7(4), 623-639. 
Komoski, K., 2007, '21st century teachers as prosumers in a bi-literate knowledgedriven global economy', in R. Carlsen, K. McFerrin, J. Price, R. Weber \& D. Willis (eds.), Proceedings of SITE 2007--Society for Information Technology \& Teacher Education International Conference, Association for the Advancement of Computing in Education (AACE), San Antonio, TX, United States of America, March Computing in Education (AAC

Kubheka, T., 2020, NZIMANDE: Online learning continues to be a key challenge during lockdown, viewed 13 May 2020, from https://ewn co za/2020/04/21/nzimandelockdown, viewed 13 May 2020, from https://ewn.co.za/2020/04/21
online-learning-continues-to-be-a-key-challenge-during-lockdown

Kumpu, M., Atkins, S., Zwarenstein, M., Nkonki, L. \& ARCADE Consortium, 2016 'A partial economic evaluation of blended learning in teaching health research methods: A three-university collaboration in South Africa, Sweden, and Uganda', Global Health Action 9(1), 28058. https://doi.org/0.3402/gha.v9.28058

Letseka, M., Letseka, M.M. \& Pitsoe, V., 2018, 'The challenges of e-Learning in South Africa', in M. Sinecen (ed.), Trends in E-learning, pp. 121-138, IntechOpen, London.

Letseka, M. \& Pitsoe, V., 2013, 'Reflections on assessment in Open Distance Learning (ODL): The case of the University of South Africa (UNISA)', Open Praxis 5(3), 197-206. https://doi.org/10.5944/openpraxis.5.3.66

Makinana, A., 2020, 'Government wants to be in charge of university laptops procurement', Times Live, 15 May, viewed 18 May 2020, from https://www. timeslive.co.za/politics/2020-05-15-government-wants-to-be-in-charge-ofuniversity-laptops-procurement/

Makoe, M., 2010, 'Exploring the use of MXit: A cell-phone social network to facilitate learning in distance education', Open Learning: The Journal of Open, Distance and e-Learning 25(3), 251-257. https://doi.org/10.1080/02680513.2010.512099

Maphanga, C., 2020, Level 4 lockdown: Students won't return to campus, risk is too great -Blade Nzimande, viewed 13 May 2020, from https://www.news24.com/ SouthAfrica/News/level-4-lockdown-students-wont-return-to-campus-risk-istoo-great-blade-nzimande-20200430

Masiu, T.M. \& Chukwuere, J.E., 2018, 'The effect of smartphones on students' academic life: A perceptive from a South African university and management dynamics', in International conference on business and management dynamics (ICBMD), Cape Town, South Africa, August 29-31, 2018, pp. 174-183.

Mayisela, T., 2013, 'The potential use of mobile technology: Enhancing accessibility and communication in a blended learning course', South African Journal of Education 33(1), 1-18. https://doi.org/10.15700/saje.v33n1a629

Mhlanga, D. \& Moloi, T., 2020, 'COVID-19 and the digital transformation of education: What are we learning on 4IR in South Africa?', Education Sciences 10(7), 180.

Moonsamy, D. \& Govender, I., 2018, 'Use of blackboard learning management system: An empirical study of staff behavior at a South African university', EURASIA Journa of Mathematics, Science and Technology Education 14(7), 3069-3082. https://doi. org/10.29333/ejmste/91623

Motala, S. \& Menon, K., 2020, 'In search of the "new normal": Reflections on teaching and learning during Covid-19 in a South African university', Southern African Review of Education 26(1), 80-99.

Mpungose, C.B., 2020a, 'Beyond limits: Lecturers' reflections on Moodle uptake in South African universities', Education and Information Technologies 25, 5033-5052. https://doi.org/10.1007/s10639-020-10190-8

Mpungose, C.B., 2020b, 'Emergent transition from face-to-face to online learning in a South African University in the context of the coronavirus pandemic', Humanities and Social Sciences Communications 7(1), 1-9.

Msiza, G.M., Malatji, K.S. \& Mphahlele, L.K., 2020, 'Implementation of an e-Learning project in Tshwane South District: Towards a paperless classroom in South African secondary schools', Electronic Journal of e-Learning 18(4), 300-310.

Msomi, A.M. \& Bansilal, S., 2018, 'The experiences of first-year students in mathematics in using an e-learning platform at a university of technology', South African Journal of Higher Education 32(5), 124-129. https://doi.org/10.20853/32-5-2507

Naidoo, V., 2017, 'E-learning and management education at African universities', in N. Baporikar (ed.), Management education for global leadership, pp. 181-201, IG Global, Hershey, PA.

National Working Group, 2002, The restructuring of the higher education system in South Africa, Report of the National Working Group to the Minister of Education, Pretoria, viewed 07 January 2021, from https://www.gov.za/sites/default/files/ gcis_document/201409/herestructure0.pdf

Ndebele, H., 2020, 'Exploring the challenges of information and communication technology localization in South African higher education: a language management approach', International Journal of Multilingualism 2020, 1-5. https://doi.org/10. 1080/14790718.2020.1717496

Ngubane-Mokiwa, S. \& Letseka, M., 2015, 'Shift from open distance learning to open distance e-learning', in M. Letseka (ed.), Open distance learning (ODL) in South Africa, pp. 129-142, Nova Publishers, New York, NY.

NSFAS, 2020a, The DHEST bursary scheme, viewed 09 May 2020, from http://www. nsfas.org.za/content/bursary-scheme.html

NSFAS, 2020b, Press release April 20, 2020 NSFAS allowances update, viewed 09 May 2020, from http://www.nsfas.org.za/content/media-releases/MEDIA\%20 RELEASE\%20-\%20NSFAS\%20ALLOWANCES\%20UPDATE.pdf
NSFAS, 2020c, Press release March 27, 2020 NSFAS update on the nation-wide lockdown, viewed 09 May 2020, from http://www.nsfas.org.za/content/mediareleases/MEDIA \%20STATEMENT\%20-\%20NSFAS $\% 20$ UPDATE $\% 200 N \% 20$ THE\%2ONATION-WIDE\%2OLOCKDOWN.pdf

O'Carroll, S., 2011, 'An exploratory study of early letter-sound knowledge in a low socio-economic context in South Africa', Reading \& Writing 2(1), 7-26. https:// doi.org/10.4102/rw.v2i1.10

Olivier, J., 2020, 'Self-directed open educational practices for a decolonized South African curriculum: A process of localization for learning', Journal of e-Learning and Knowledge Society 16(4), 20-28.

Ramaphosa, C., 2020, 'SA on coronavirus lockdown: Read President Cyril Ramaphosa's full speech', 23 March, viewed 07 April 2020, from https://www.iol.co.za/news/ politics/sa-on-coronavirus-lockdown-read-president-cyril-ramaphosas-fullspeech-45429127

Rohleder, P., Bozalek, V., Carolissen, R., Leibowitz, B. \& Swartz, L., 2008, 'Students' evaluations of the use of e-learning in a collaborative project between two South African universities', Higher Education 56(1), 95-107. https://doi.org/10.1007/ s10734-007-9091-3

Saavedra, J., 2020, Educational challenges and opportunities of the Coronavirus (COVID-19) pandemic, viewed 29 April 2020, from https://blogs.worldbank.org/ education/educational-challenges-and-opportunities-covid-19-pandemic

Sebolai, D. \& Ogutu, F., 2012, 'Electronic learning as a tool to enhance teaching and learning process: A case of Taletso FET College', Proceedings of the 12th European Conference on e-Government ECEG, Barcelona, June, 14-15, 2012, pp. 416-423.

Shoba, S., 2020, Tertiary education academic year set to continue into 2021, viewed 13 May 2020, from https://www.dailymaverick.co.za/article/2020-05-01-tertiaryeducation-academic-year-set-to-continue-into-2021/

South African Government, 2020a, 'President Cyril Ramaphosa: South Africa's response to coronavirus COVID-19 pandemic', April 23, viewed 13 May 2020, from https://www.gov.za/speeches/president-cyril-ramaphosa-south-africasresponse-coronavirus-covid-19-pandemic-23-apr-2020

South African Government, 2020b, 'Minister Blade Nzimande: Measures to phase out the Coronavirus COVID-19 lockdown and phasing in of PSET strategic functions', April 30, viewed 13 May 2020, from https://www.gov.za/speeches/ministerblade-nzimande-measures-phase-out-coronavirus-covid-19-lockdown-andphasing-pset

Statistics South Africa, 2018, General household survey 2018, viewed 06 August 2020 from http://www.statssa.gov.za/publications/P0318/P03182018.pdf.

Statistics South Africa, 2019, Education series volume V higher education and skills in South Africa, 2017, viewed 09 January 2021, from http://www.statssa.gov.za/ publications/Report-92-01-05/Report-92-01-052017.pdf

Stoltenkamp, J. \& Kasuto, O.A., 2011, 'E-Learning change management and communication strategies within a HEI in a developing country: Institutional organisational cultural change at the University of the Western Cape', Education and Information Technologies 16(1), 41-54. https://doi.org/10.1007/s10639-0099114-z

Sulla, V. \& Zikhali, P., 2018, Overcoming poverty and inequality in South Africa: An assessment of drivers', constraints and opportunities (English),World Bank Group, Washington, DC, viewed 09 January 2021, from http://documents.worldbank. org/curated/en/530481521735906534/Overcoming-Poverty-and-Inequality-inSouth-Africa-An-Assessment-of-Drivers-Constraints-and-Opportunities

Swartz, R., Ivancheva, M., Czerniewicz, L. \& Morris, N.P., 2019, 'Between a rock and a hard place: Dilemmas regarding the purpose of public universities in South Africa', Higher Education 77(4), 567-583.

Tewari, D.D. \&llesanmi, K.D., 2020, 'Teaching and learning interaction in South Africa's higher education: Some weak links', Cogent Social Sciences 6(1), 1740519. https:// doi.org/10.1080/23311886.2020.1740519

UNESCO, 2011, UNESCO and education: 'Everyone has the right to education', The United Nations Educational, Scientific and Cultural Organization, Paris.

UNESCO Institute for Information Technologies in Education, 2020, Combat COVID-19: Keep learning. Together we are on the move!, viewed 29 April 2020, from https:// iite.unesco.org/combating-covid-19-together-we-are-on-the-move/

Universities South Africa, 2021, Public universities in South Africa, viewed 09 January 2021, from https://www.usaf.ac.za/public-universities-in-south-africa/.

WHO, 2020, Coronavirus disease (COVID-19) pandemic, viewed 13 May 2020, from https://www.who.int/emergencies/diseases/novel-coronavirus-2019

Winter, J., Cotton, D., Gavin, J. \& Yorke, J.D., 2010, 'Effective e-learning? Multi-tasking distractions and boundary management by graduate students in an online environment', ALT-J 18(1), 71-83. https://doi.org/10.1080/09687761003657598

Worldometers, 2020, COVID-19 coronavirus pandemic, viewed 01 May 2020, from https://www.worldometers.info/coronavirus/

Yang, X., 2010, 'The globalization and localization of "learner-centered" strategy from an international horizon', Asian Social Science 6(9), 78-81. https://doi. org/10.5539/ass.v6n9p78

Zimba, Z.F., Khosa, P. \& Pillay, R., 2020, 'Using blended learning in South African social work education to facilitate student engagement', Social Work Education 40(2) 263-278. https://doi.org/10.1080/02615479.2020.1746261 